\title{
THE IMPACT OF THE PRINCE EDWARD ISLAND SCHOOL LIBRARY POLICY ON THE DEVELOPMENT OF SCHOOL LIBRARY PROGRAMS ACROSS PRINCE EDWARD ISLAND
}

\author{
Ray Doiron \\ Faculty of Education \\ University of Prince Edward Island \\ 550 University Avenue \\ Charlottetown, Prince Edward Island Canada \\ E-mail: raydoiron@upei.ca \\ Judy Davies \\ Resource-Based Learning Consultant \\ Department of Education \\ Province of Prince Edward Island, Can ada \\ E-mail: jadavies@gov.pe.ca
}

\begin{abstract}
In Canada's smallest province, Prince Edward Island (PEI), the PEI School Library Policy and its supporting documents have guided the development of school library programs since 1989. With a great number of educational changes as a back-drop, this study explored the impact that policy has had on school library programs in PEI. The researchers designed a comprehensive Survey of School Library Resource Centres that probed five key areas: facilities, resources, personnel, programs and services in the 66 schools across PEI. Following the completion of the Survey, 48 principals and teacher-librarians were interviewed for an hour each. 64 of the 66 schools took part and the Survey data and the interview data were analyzed using exploratory data analysis that resulted in dozens of visual and numerical summaries. Data was reported under each of the five major areas probed and 25 Actions were recommended.

The study yielded specific detail on the status of school library facilities and resources, and provided a comprehensive look at staffing procedures and problems. The educational concepts of resource-based learning, cooperative planning and information skills that are embedded in the Policy have been well-accepted across the system. New documentation is needed to update learning outcomes and to provide direction for integrating new technologies and the concept of information literacy. Future directions for professional development for teacher-librarians, principals and classroom teachers were outlined and specific needs were identified in the areas of staffing, rebuilding school library collections and connecting technology initiatives and resource-based learning.
\end{abstract}

\section{BACKGROUND FOR THE STUDY}

It is a time of great change in the education system in the Canadian province of Prince Edward Island (PEI). Restructuring has led to streamlined administrative jurisdictions, centralized curriculum services and a struggle amongst educators to redefine roles and identify new goals within the rapidly changing educational context. Throughout the change process, all areas of the education system have been examined to identify ways and means of streamlining program delivery and providing more effective and efficient programming for students. This has led PEI into collaborative relationships with the other provinces in Atlantic Canada in the areas of curriculum development, standard learning outcomes and consistent assessment procedures.

Coupled with the changes in curriculum and administration has been the growing influence of new educational technologies, particularly computers, on classroom and school library programs. 
While instructional technology has always had an influence on what educators do, the pervasive nature of computers has led to unprecedented change in the delivery of instructional services. New initiatives by governments have had a tremendous impact on the availability of computer hardware and software and all educators are feeling a growing pressure to hone their computer skills and integrate their use into their instructional programs. The school library community has been active in the transition from manual management systems to fully automated ones, as well as showing leadership in understanding the role of computer technology in developing information skills and making effective use of the information problem-solving process.

Coming out of this change process was the expectation that all educators spend some time reflecting on the objectives of past programs and set new goals in light of our contemporary understanding of curriculum delivery and of greater expectations from learners and society, in general, to develop the knowledge and skills needed for life in the next century. Since the school library resource center has played a role in the instructional program of most schools in PEI, it was natural that the focus turn to school libraries to examine what had been accomplished since the implementation of the PEI School Library Policy in 1989.

The PEI School Library Policy Statement ( PEI Department of Education, 1989) established school libraries "as an essential element of the educational process for students at all levels of the school system." It set two main goals for library programs- the development of information skills and the use of these skills to ensure lifelong learning. It further established resource-based teaching/learning as the best way to achieve these goals through "a library program fully integrated with the school's instructional program with teacher-librarians and teachers using a cooperative program planning and teaching approach." These principles of an integrated school library program, resource-based learning, the role of the teacher-librarian and cooperative program planning and teaching have guided school library programs in PEI for eight years and were the impetus for many professional development activities for teacher-librarians, administrators and classroom teachers.

Following the PEI School Library Policy Statement, the PEI Department of Education issued a set of School Library Resource Centre Guidelines (1992), which outlined a set of "recommended standards" for PEI schools in the areas of school library program, personnel, collections, equipment and facilities. While they were not mandated by the Department, these guidelines acted as points of reference for district level policy implementers, school-based administrators and front-line teacherlibrarians as they implemented the PEI School Library Policy. An Information Skills Continuum was also developed and issued as a support document for school library program development.

These three major documents set the school library community on a course that would see new teacher-librarian positions created by the Department's direct support of "outside-the pupil/teacher-ratio" positions, program initiatives by Department and district-level consultants, the implementation of a ten-course Diploma Program in School Librarianship by the University of Prince Edward Island, the development of district-level school library policies, plus a concerted effort by many individual teacher-librarians to make the goals of the Policy and Guidelines a reality in the province. Many teacher-librarians led numerous professional development activities for their staffs and colleagues to bring about the awareness that the school library was no longer simply a storeroom for resources, but an integral part of curriculum in all schools.

An informal examination of the results of these government and professional efforts indicated that successes were inconsistent. Many educators recognized the benefits of an integrated school library program, the need to teach students information skills and to nurture information literacy, as well as the importance of developing programs that foster lifelong learning. Some schools fully embraced these goals and built excellent school library programs, while others made important gains, but were still struggling to fully implement the Policy. Regrettably, other schools made few changes in their school libraries and they continued to place the goals of the Policy low on their list of new initiatives. It became apparent that after eight years with the PEI School Library Policy Statement as the main force guiding the development of school libraries in PEI, coupled with over twenty years of personal commitment by many teacher-librarians, the time was right for a serious examination of school libraries in PEI. It followed that any formal reflection on what was happening with school libraries would allow educators to celebrate their accomplishments and then set new goals that respected the principles outlined in the Policy, and that meshed with current curriculum initiatives across the country. 
In summary, several compelling factors suggested the need for a formal examination of the status of school libraries in PEI and led to this study:

- There is a growing demand for change in education that has focused on the role of technology in learning, the goals of lifelong learning, as well as the establishment of more accountability among all partners in the education process;

- All aspects of the education system are under pressure to examine what they do and to see how well they will facilitate the meeting of these new expectations. For the school library community that meant examining the impact of the Department of Education's School Library Policy Statement to see how effective it has been over the past eight years;

- The principles entrenched in that Policy, such as resource-based learning, lifelong learning, integration of program goals and cooperative planning/teaching seem to have spread beyond the school library context and are now included in the new curriculum documents that are driving change across the Atlantic provinces. This indicated that the philosophy of the integrated school library was on the right track and, with the support of local research, could emerge as a pervasive and influential model across all areas of the curriculum;

- It appeared that strong gains had been made in school libraries over the past few years, but still, there are glaring inconsistencies in many school library programs across the province. Questions needed to be asked about how effective the Policy has been, how realistic the Guidelines are and what influences continue to limit the progress schools have made? How successful have schools been at implementing the School Library Policy and achieving the standards outlined in the Guidelines? Is there evidence for alternatives to addressing some of the limitations currently inhibiting progress for school libraries?

\section{THE RESEARCH PROCESS}

This study examined the impact that the School Library Resource Centre Policy has had on elementary and secondary schools in PEI. It focused on collecting information on the status of services, facilities, personnel, resources and programs currently available in PEI school library resource centers. All schools were invited to take part and two instruments were used to collect quantitative and qualitative information. First of all, a general survey on school library resource center services and programs was sent to all 66 schools in PEI. It provided a wide-angled report on conditions in PEI schools after eight years of efforts to implement the Policy. Secondly, 48 one-toone interviews with administrators and teacher-librarians or library contacts gave an up-close look at the situations found in a sampling of 24 schools chosen for geography, school size and school district.

Data was analyzed using a series of exploratory data analysis (EDA) techniques which generated visual and numerical summaries of the results, such as graphs and summary tables. These results were presented within the five areas of investigation-services, facilities, personnel, resources and instructional programs.

The emphasis in the reporting and dissemination of the results was on presenting them pragmatically and in terms of future plans of action that meshed with current Department curriculum initiatives and future innovations. Twenty-five recommended actions for future development of the Policy were made, as well as suggestions for the maintenance of existing programs.

\section{The Survey of School Library Programs in PEI}

The principal instrument used in the study, the Survey of School Libraries in Prince Edward Island ( the Survey), was constructed by the researchers to examine five key areas outlined in the PEI School Library Policy and the School Library Resource Center Guidelines.

Each area of the Survey consisted of questions requiring a 'yes/no' answer or the choosing of a response from a five-point scale that was closest to the participants' experience. Questions were drawn from the expectations outlined in the School Library Resource Centre Guidelines and the lists of components of a comprehensive library program as outlined in the School Library Policy 
Statement. The following is a breakdown of the general areas used in the Survey and of the specific topics probed under each section:

- Facilities. Participants answered questions on the size of their facility, general features of the facility, seating capacity, shelving, collections areas available, as well as computer facilities.

- Personnel. Questions in this section centered on the staff allocation for the school library, the inside/outside the school ratio proportion (i.e., time added from the Department of Education), the use of support staff, the level of professional training and teaching experience of school library personnel, involvement of library personnel in professional activities, as well as their future professional development needs.

- Resources. This was the largest section of the Survey. The availability of various types of resources was probed including fiction and nonfiction books, reference materials, periodicals, AV/computer software, equipment and the information file. For each area, participants indicated a number of the items in the school library and then rated that part of the collection for currency, size, reading level, match to students' reading interests and match to the school's curriculum needs. A small section on the school library budget focused on the size of that budget, as well as funds received from book fairs, school fund raising and donations. Resource management was probed with questions on selection of resources, purchase and processing of resources, weeding and donations.

- Services. Participants gave an indication of their frequency of use of external sources to provide resources for the school library, supplying resources to classrooms, how book exchanges are handled, how students access the instructional program and what technical support for $\mathrm{AV} /$ computer hardware and software they provide teachers.

- Instructional Program. Questions in this section concerned whether the school had a school library policy and/or a plan for information skills development. Teacher-librarians were then asked the percentage of their allocated time spent on instruction, planning and management. At the end of each section of the Survey, participants were invited to write any 'other' comments they wished. Almost everyone used the spaces provided and all of the 'other' comments were transcribed and included in the data analysis.

\section{Procedures}

All 66 public schools in Prince Edward Island were sent a copy of the Survey in December, 1995 and invited to take part. Administrators in the school districts and their teacher-librarian or library contact had been notified earlier in November and told about the purpose of the research and the procedures that would be used. Department of Education and district level staff facilitated the process by encouraging all schools to participate. In total, 64 of 66 schools responded by February 1996 for a 96.9\% response rate. This is an extremely high return rate and it reflects the deep commitment and interest of teacher-librarians and library contacts. As the Surveys were returned, the results were entered into a database for later analysis. The accuracy of data entry was verified by having an independent assistant check the data entry on a random sample of $20 \%$ of the Surveys.

\section{The Interviews}

As the Surveys were completed, plans were finalized for the second part of the study - a set of research interviews. Out of an early examination of the Survey results, several questions were raised and became part of the set of interviews that followed. Questions were also included from each of the five areas under investigation.

After the questions were designed, procedures began for identifying which schools would be contacted and invited to take part in a one-hour interview. With 66 schools to cover, it was impossible to interview everyone, so a representative sampling of schools took into consideration the geographic location of the school, the school population and the school type. A balance of all these factors, plus a commitment to interview at least one-third of the schools, led to the choosing of 24 principals and 
24 teacher-librarians/library contacts to take part in the interviews. Table 1 gives the distribution of schools used in the interviews.

Geography

Prince County: 8 Queens County: 9 Kings County: 7

School Type

Elementary: 7 Junior High: 1 Senior High: 5 Elem/JrHi: 6 French: 1

School Size

under 250: 5 250-400: 5
Table 1: Distribution of Interviews

400-550: $4 \quad$ 550-700: 4 over 700: 6

$-$

All interviews were conducted by the same researcher, were recorded and later transcribed for analysis. A random sample of $20 \%$ of the completed interviews and transcriptions was verified by the second researcher. Response to the interviews was very positive; all who were contacted agreed to take part and they repeatedly stated how pleased they were to address the issues of school library programs in PEI. The interviews were conducted during late February and March and the transcription and analysis processes were on-going as the interviews were completed. With the Surveys and interviews completed and the data entered and the transcriptions checked for accuracy, the main data analysis began.

\section{Analysis of the Survey Findings}

Results of the Survey were analyzed by grouping responses within the five areas under investigation-facilities, personnel, resources, services and program. Questions that were related to similar issues were grouped under one of the five principal areas. For example, the general area of school library facilities, community use of the facility and in-school use of the facility were examined together. In the area of school library personnel, questions about clerical staff, use of volunteers and use of student library monitors were grouped under support staff. These categories were then examined by school type, either elementary (grades 1-6), junior high (grades 7-9), senior high (grades 9/10-12), elementary/junior high (grades 1-8/9) and French (grades 1-12).

A second analysis of the same data was done by regrouping the results into categories based on full-time equivalent (FTE) staffing allocated to the school library. These categories were: 0-FTE (no teacher-librarian, just a library contact); .1 to $.3 \mathrm{FTE}$; .31 to $.55 \mathrm{FTE}$; 6 to $.99 \mathrm{FTE}$; and equal to or greater than 1 FTE $(=>1)$. Table 2 below, outlines these categories and the number of respondents in each FTE category. This analysis by FTE made it possible to identify differences on variables according to the amount of time the respondent was working in the library position.

Table 2: Category of SLRC Personnel by Full-Time Equivalent (FTE) Staff Allocation

$\begin{array}{ccc}\text { FTE Category } & \text { Number of Positions } & \% \text { of Total } \\ 0-\text { FTE } & 13 & 20.31 \% \\ .1-.3 \text { FTE } & 8 & 12.50 \% \\ .31-.55 \text { FTE } & 10 & 15.63 \% \\ .6-.99 \text { FTE } & 11 & 17.19 \% \\ =\text { or }<1.0 \text { FTE } & 22 & 34.38 \% \\ \text { TOTAL } & 64 & 100.00 \%\end{array}$

With the data organized by category of school library topic, by school type and by FTE, a series of descriptive graphs were generated that presented the results as visual summaries. This 
method was in keeping with the research goal of examining the results as a 'snapshot' of what conditions were like at one point in time. No attempt was made to assign causality to the relationship amongst the variables-simple description of the results was the goal. The graphs were simple bar graphs or line graphs which make it easy for the reader to 'see' what is happening.

\section{Analysis of the Interviews}

Once the transcriptions of the recorded interviews were completed, analysis was organized by type of respondent, either principal or teacher-librarian/library contact. A holistic analysis was done first which consisted of listening to the tapes and reading the printed transcriptions. Important themes and general trends were noted. This was followed by a more detailed examination of individual questions across all respondents in which each different response was recorded and counted. The number of times an answer was given was noted and the salient points or recurring themes were tracked. Quotes from the text that represented typical responses were recorded for inclusion in the reporting of results.

\section{A SUMMARY OF THE RESEARCH FINDINGS}

The analysis of the Surveys and the interviews yielded a wealth of detailed information on dozens of topics within each of the major areas investigated. Space limitations do not permit the reporting of the findings in such great detail here and so a series of research summaries are presented in order to encapsulate the key findings under school library facilities, school library personnel, school library resources and the combined areas of school library services and programs.

\section{School Library Facilities}

The school library facilities averaged over 1700 square feet, and were reported to be open for students and teachers most of the time. The students and teachers in the school used the school library facility for a variety of purposes, other than as a school library, and the community also used the facility as a meeting place for various events. Almost all school libraries reported space for a reference collection and for collections of fiction and nonfiction trade books. Other collection areas, such as periodicals, professional materials, AV/computer software and information files were found in varying degrees in the facilities. Variance was also found in the type of seating available for students. If a school library facility could accommodate whole classes, small groups, independent study and quiet reading, respondents felt they were better able to meet the varied needs of an integrated school library program.

Computer facilities are rapidly changing in all school libraries. The number of computers available in the school library is growing, but many respondents still reported limited access to lab facilities and only one multimedia workstation. Access to the Internet and networked systems was also increasing, but they were often described as emerging as parallel services for teachers and students, rather than as integrated components of a school-wide plan for information literacy.

In discussions with teacher-librarians/library contacts and school principals, several recurring themes were identified. There was a need to coordinate the installation of new educational technologies in the school with the technology needs of the school library facility. In many cases, plans were racing ahead for adding computer labs, on-line services, networks and software applications without any knowledge of what the school library had already accomplished in automation and in providing computers for accessing databases and word processing. Collaboration is needed by all educational partners to streamline the duplication of effort and also to promote the development of expertise by different partners for areas in which they can contribute the most to the overall information literacy needs of students. Part of that collaboration is recognizing the future potential for the school library.

Schools with open-area libraries or single-classroom/double-classroom facilities were found to have a set of problems rooted heavily in the nature of their facility. It appeared that newer schools came closer to matching the expectations of the School Library Policy and the School Library Resource Centre Guidelines documents, while schools with open area facilities were limited by noise and traffic problems, lack of walls and poor display space, as well as limited or inadequate storage facilities. The single-classroom/double-classroom facility seemed limited by its small size and lack of room to grow. Many of these facilities were designed and built at a time when a school library 
program was limited to reading stories to children and signing out books. Several respondents felt they were limited by their facility in developing a program that included more research by students, more independent resource-based learning projects and activities that include the use of technology. It appeared that these facilities will continue to deteriorate unless a concerted effort is made to address the limitations imposed by the facility itself.

With such a variance in the state of school library facilities and with such a wide range of individual needs, it is necessary to take a different approach in dealing with improvements to these facilities. It is impossible to recommend one action or set of actions to alleviate the problems. The province has a set of Guidelines and a clear vision for what the school library program should be like. What is needed is a team approach to the situation where other practitioners could visit a school library and provide assistance to a committee of teachers in the school to develop a long-range plan of action that would address the specific needs of that school library facility. The Department of Education could support this model as a professional development activity by providing release time for people to visit schools and consult with staffs as they develop an improvement plan. Individual school districts could encourage schools to develop strategies for implementing their improvement plans that would include budget plans for maintenance and renovation. Improvements to school library facilities could be achieved with a collaborative approach. In this way, the plan of action could be kept realistic, and thus more attainable, since it would emerge from the school base and would be supported in a collegial way by all education partners.

\section{School Library Personnel}

Staffing issues continue to dominate the development of successful school library programs in this province. Findings indicated that staffing is holding at consistent levels over the past few years, but that staffing below the .5 FTE level is still too common. Small schools with a population below 200 students had no staff and relied on a classroom teacher volunteering to be the library contact for that school and look after the facility. The designation of library contact positions needs to be reassessed since in many ways these individuals are acting as teacher-librarians with no time to do the work. This results in the illusion of staffing being created with no real gains for the school library program.

It was also noted that there are some wide variances in the staffing of school libraries with schools of the same size having very different allocation of staff to the teacher-librarian position. For example, one school of 400 students allocated .4 FTE for teacher-librarian, while another school of 408 allocated .8 FTE and a third of 354 students allocated 1.0 FTE. The recommendation was made that a new set of staffing guidelines be issued to clarify the 1.0 FTE to 400 students ratio as previously suggested in the provincial Guidelines and to stimulate new initiatives in the staffing of school libraries. Table 3 below outlines the recommended staffing guidelines.

Table 3: Staffing Allocation for Teacher-Librarian FTE

School Size
over 800
$400-800$
400
$200-400$
$<200$

Staffing Allocation

1.5 FTE plus 1.0 clerk

1.0 FTE plus .5 clerk

$1.0 \mathrm{FTE}$

.5 FTE

.5 FTE ( 2 or more schools share)

A great deal of discussion centered around the Department of Education's program to provide outside-the-ratio positions to support FTE teacher-librarian positions. The use of these outside-the-ratio positions seemed to result in some serious differences in the way they were awarded and used across the system. It was recommended that this program be maintained and increased, but that more accountability be attached to the awarding of such positions to schools.

Improvements in the qualifications of teacher-librarians were noted, due to the success of the Diploma in School Librarianship at the University of Prince Edward Island, and various provincial, 
district and in-school professional development efforts over the past few years. Teacher-librarians and library contacts indicated very different professional development needs. Those with smaller FTE wanted support with management issues while those in full-time positions were looking for help in curriculum and program areas. Suggestions were made to identify more specifically future professional development needs and for the development of a long-range plan for teacher-librarian professional development. Efforts also are needed to share the accomplishments of many front-line teacher-librarians who have developed exemplary programs, many in spite of some serious limitations.

\section{School Library Programs and Services}

The quality and comprehensiveness of school library programs and services was seen as directly related to the percentage of allocated time for the position of teacher-librarian. The more time allocated to the position of teacher-librarian, the larger the amount of time that could be given to instruction and cooperatively planning with teachers. Those in positions with less than .5 FTE spent a greater proportion of that time on the management duties associated with operating a school library resource center. There seems to be a critical mass of time needed in the teacher-librarian position before a comprehensive instructional program can develop, one that is in line with the goals outlined in the PEI School Library Policy. The same findings held for the use of time for planning-the larger the FTE, the more time was spent planning with teachers, the more times the Information Skills Continuum was used and the more meetings were held with principals.

School library programs were described in one of three ways: as limited, focused on book exchanges and some isolated teaching of skills; as parallel, where the teacher-librarian complemented the classroom teacher's program; or as collaborative, where instruction was integrated with classroom programs. Strengths were seen in the area of providing instruction, providing resources and in working with classroom teachers. Principals added that strengths were in the teacher-librarian as a strong leader and collaboration with classroom teachers. Major weaknesses were in the staffing allocation for the teacher-librarian position and the resource collection.

The interviews suggested that the concepts embedded in the School Library Policy are well understood and accepted. The need for classroom teachers to have a greater understanding of these same concepts was identified as a major in-service need. Many participants felt that the Department of Education needed to send a clear message of support and commitment to the educational community to clear the air of uncertainty from the future of school libraries in PEI. Many of the future professional development activities should focus on creating a climate for collaboration that will bring teachers together to build resource-based learning and many of the other educational concepts embedded in several of the educational documents that are currently influencing the school system. Participants also identified the need to update the School Library Policy and the other school library documents to bring them more in line with current thinking on information literacy.

\section{School Library Resources}

Although elementary and elementary/junior high school collections met the minimum expectation of 15 books-per-student as recommended in the Guidelines; other school types did not. Nonfiction collections were identified by all levels as inadequate to meet curriculum needs and student reading levels. Trade book collections also had more fiction than nonfiction, a balance that did not meet the recommendations in the Guidelines. Table 4 summarizes the book-per-student numbers by school type.

Table 4: Books-per-Student by School Type

$\begin{array}{lccccc} & \text { Elementary } & \text { Junior High } & \text { Senior High } & \text { Elem/Jr High } & \text { French } \\ \text { Easy Fiction } & 4.94 & 0.65 & 0.59 & 4.78 & 7.69 \\ \text { Fiction } & 4.86 & 4.69 & 2.67 & 7.38 & 8.38 \\ \text { Nonfiction } & 6.15 & 5.00 & 8.19 & 7.41 & 10.21 \\ \text { Total } & 15.95 & 10.34 & 11.45 & 19.57 & 26.28\end{array}$


Reference collections had a wide variety of different types of items in them but concerns were expressed about the currency of the materials and the size of collections to meet the demands of student research projects and teachers' programs. Information files were found mostly in schools with enough time allocated to the teacher-librarian position to allow for time to be spent keeping the information current.

Many concerns were raised about the state of repair of audio/visual equipment and software. Many reported these resources out-of-date and not well matched to current curriculum needs. Concerns were also expressed about future maintenance of the new computer hardware and software currently enjoying favor across the system. Periodicals were reported heavily used in senior and junior high schools, but ratings for their match to student interest and reading level were low.

Almost all school libraries reported that a budget was given each year to buy learning resources. Some funds were also raised from book fairs, with minor amounts from community groups or other fund raising. Concerns were expressed about situations where the teacher-librarian had little input into the budget process so that resource collections could not be developed with any consistent budget allocation. It was a universal concern that more money for resources is needed if collections are to be brought up-to-date and enlarged to meet the demands from current curriculum and resource-based learning projects.

The current school library collections need financial support from government over the next few years in order to alleviate the present poor condition of collections and to give students and teachers the resources they need for curriculum endeavors. Recommendations were made for the development of a centralized selection system for school library collections that would establish a process for new curriculum resources to be selected and made available for the local school library. Liaison with the Provincial Library system, publishers and all levels of program implementation would be essential to facilitate the success of this system.

It was suggested that individual schools also set up plans for collaboration on the collection development process to include setting consistent budgets for resources, writing collection development plans and including teachers in the selection process. Linked to the issues around the state of school library collections was the need to update the PEI School Library Resource Centre Guidelines and the Information Skills Continuum to reflect more accurately the curriculum and resource needs of students and teachers.

\section{MAJOR FINDINGS}

Several summative statements can be made across all five areas investigated and from both research instruments.

- There has been a general growth and acceptance of the principles of resource-based learning, the role of the teacher-librarian, cooperative program planning and teaching and the integrated role of the school library program. No suggested changing out these concepts and come up with something new. In fact, with the emphasis recently placed on resource-based learning by the Atlantic Province Education Foundation (APEF) documents, participants felt the concepts had been reinforced and validated. The discussion in this study was on the factors that inhibit the full realization of the potential these concepts offer, rather than suggesting the concepts are unfounded or not important to current curriculum activities.

- Participants felt strongly that the Policy, Guidelines and Information Continuum needed to be up-dated to reflect the influence of technology on the role of the school library and to set direction for the use of the concept of information literacy as a more inclusive way of expressing the role that school libraries and the teacher-librarian should play in the school curriculum. A set of learning outcomes needs to be developed out of the Information Continuum to match the current regional initiatives to describe programs in terms of expected outcomes. The documents need to be re-packaged into a single information literacy document that includes examples of 'best practices', as well as detailed suggestions for classroom teachers and teacher-librarians for implementing resource-based learning and the cooperative planning process. 
- Participants expressed a need for the Department of Education to make it clear that it still sees the school library and the role of the teacher-librarian as a vital and integral part of its curriculum goals for the province. A 'dark cloud' hangs over the teacher-librarian community as members wonder whether PEI will have its school library programs "gutted" or whether they will continue to receive support from the Department. They wonder if they should bother with the effort it will take to continue schools on a road toward full realization of the potential for school libraries. The Department needs to take some action that will clear the air of uncertainty for teacher-librarians and reiterate its commitment to school libraries and support them to get on with the job.

- There is clear evidence from the study of the inextricable link among the school library program, the personnel hired to develop the program and the resources needed to fully implement the program. We can say that more resources is not the answer, or more staffing will not solve the problem, but the reality indicates that there is a critical mass for both staffing and resources below which a school library program cannot develop. A positive finding of the study was that there are many examples of some exemplary programs when all three come together. That is not to suggest that these programs are perfect either, but with the basic pieces in place, such as at least a .5 FTE teacher-librarian, some great things can start to happen.

- Teacher-librarians and administrators saw a need to broaden the implementation process for school library programs to include more efforts aimed at curriculum consultants and classroom teachers. Many found these teachers were not knowledgeable about the vital role played by the school library or the value of having a teacher-librarian in the school. Past efforts have been aimed at teacher-librarians, library contacts and administrators, but indications were that classroom teachers and those developing new programs needed to be made aware of their role in the overall plan for resource-based learning and the integrated school library program. Suggestions were also made that there are many new administrators in the system and that many of them had not received in-service training on the goals of the PEI School Library Policy. They were also seen as a group needing support in finding creative solutions to some of the managerial problems that stand as roadblocks for some in the full implementation of an integrated school library program.

- Future curriculum development plans need to be made with the goal of making connections, whenever possible, with the school library program. If new programs are being piloted, then the teacher-librarian in that school should be included so he or she could 'pilot' the resource-based learning aspects for the new program. Stronger connections also need to be drawn between new program initiatives and collecting information on existing resources to support the program or new ones that will be need to be acquired.

- Several major issues related to staffing school libraries and up-grading school library collections will have to be addressed if the philosophy of the school library program is to be fully realized. Efforts need to be made to provide all school libraries with at least a .5 FTE position for the teacher-librarian and for support staff for libraries in larger schools. More detailed information on resources and equipment needs to be gathered and ways of streamlining the selection and ordering of resources need to be found. Budgets need to be increased to help bridge the gap that has developed over the past few years in school library collections that have not been able to keep an adequate supply of current and relevant resources.

- In some schools, the facility used for the school library is inadequate for fully implementing a school library program. Some facilities cannot accommodate more than a few children at once and several were having difficulties integrating the new information technologies because of the limitations of the facility. Single or double classrooms converted into a school library and several of the open plan school library facilities present special problems. While some of these difficulties will need a major renovation to alleviate the problems, efforts could be made to take small steps now to improve the situation. 
- Collaboration across the system, within the school and between teacher-librarians and administrators was identified as a crucial determinant of success for the school library program. Schools that were successful at implementing the school library program were places where the principal and the teacher-librarian communicated frequently about the school library program and the school in general was a place where teachers collaborated in a collegial climate. Professional development across the system needs to focus on the collaborative nature of change and place more direct effort in helping all educators apply collaborative principles. This will facilitate all aspects of curriculum development, but will be especially important to implementing a school library program.

\section{AN OPPORTUNITY FOR RENEWAL}

These nine major findings form the framework for a general renewal of school library programs in PEI. They are rooted in a comprehensive and broad research base; they recognize the accomplishments of the past and set out the challenges for the future; they provide a strong direction for future curriculum endeavors; they clarify the major limitations on existing programs; they provide concrete suggestions for addressing some of the issues affecting school library programs. What needs to be provided now is an opportunity for the school library community, educators across the system and Department of Education officials to enter into a discussion about the implications of the study and to define the next course of action. Most of the findings and many of the suggested actions need to be incorporated into existing structures and programs and will develop over time, while others need immediate action and new initiatives.

\section{REFERENCES}

Prince Edward Island Department of Education. (1989). The PEI School Library Policy Statement Prince Edward Department of Education. (1992) School Library Resource Centre Guidelines. (1992) PEI School Library Policy. An Information Skills Continuum. 